\title{
High-growth firms and productivity: evidence from the United Kingdom
}

\author{
Jun Du • Yama Temouri
}

Accepted: 23 April 2014/Published online: 17 May 2014

(C) The Author(s) 2014. This article is published with open access at Springerlink.com

\begin{abstract}
There is considerable evidence that highgrowth firms (HGFs) contribute significantly to employment and economic growth. However, the literature so far does not adequately explore the link between HGFs and productivity. This paper investigates the empirical link between total factor productivity (TFP) growth and HGFs, defined in terms of sales growth, in the United Kingdom over the period 2001-2010, by examining two related research questions. Firstly, does higher TFP growth lead to HGF status and secondly, does HGF experience help firms achieve faster TFP growth? Our findings reveal that firms in both the manufacturing and services sectors are more likely to become HGFs when they exhibit higher TFP growth. In addition, firms that have had HGF experience tend to enjoy faster TFP growth following the high-growth episodes. Policy implications are drawn based on the self-reinforcing process
\end{abstract}

Electronic supplementary material The online version of this article (doi:10.1007/s11187-014-9584-2) contains supplementary material, which is available to authorized users.

J. Du $(\bowtie) \cdot$ Y. Temouri

Economics and Strategy Group, Aston Business School, Aston University, Birmingham B4 7ET, UK

e-mail: j.du@aston.ac.uk

Y. Temouri

e-mail: y.temouri1@ aston.ac.uk

J. Du $\cdot$ Y. Temouri

Enterprise Research Centre, Birmingham, UK of the high-growth phenomenon that is revealed by our results.

Keywords Productivity · Firm growth $\cdot$ Highgrowth firms

JEL Classifications $\quad$ D24 $\cdot$ L11 $\cdot$ L25 $\cdot$ L26

\section{Introduction}

The concept of high-growth firms (HGFs) has attracted significant interest by governments and policy makers across many countries. This has developed from the evidence offered by the growing literature on small business economics and entrepreneurship. A relatively small number of HGFs play a disproportionately large role in the economy (Storey 1994; NESTA 2011). Policy makers are thus very keen on supporting HGFs with various initiatives to help sustain and expand this key source and potential driver of economic growth, innovation, and wealth creation (Acs et al. 2008; OECD 1998, 2000, 2002). In understanding the nature and characteristics of such exceptional firms, the literature has identified a number of stylised facts which HGFs appear to have in common (Henrekson and Johansson 2010a).

However, we know very little about any association between productivity and the incidence of HGFs. This is of particular importance, given that firm-level productivity, alongside other firm-specific capabilities, 
such as innovativeness, technological and managerial know-how, has the potential to be translated into firm employment and output growth (Dunning and Cantwell 1991; Horstmann and Markusen 1989; Mason et al. 2009; Kirca et al. 2011). In particular, total factor productivity (TFP) is now widely recognised as an important driver of both long-run economic growth and short-run growth fluctuations.

There are several reasons that lead one to expect a positive relationship between productivity and HGFs. Theoretical and empirical evidence shows that the levers that managers can use to improve business performance and productivity include managerial practice and talent, employee and input quality, information technology, $\mathrm{R} \& \mathrm{D}$, product innovation, organisational structure and learning by doing (Syverson 2011). Several of these factors may relate to what drives HGFs, even though few have been tested in the literature. For example, HGFs outperform their rivals with the ability to exploit their previous investments in successful innovation. Mason et al. (2009) find that innovative UK firms grow twice as fast compared with other firms that do not innovate. Mason and Brown (2010) find that being knowledge-based and innovative defines the characteristics of most HGFs in Scotland and is a key driver of the spectacular growth resurgence in the United States (Jorgenson et al. 2005; Oliner et al. 2008). In addition, it also explains the gap between the European and US productivity experience over the last few decades (Van Ark et al. 2008). Furthermore, a firm's core competences of high-quality output and their employees' knowledge of the market and customer seem to be associated with HGFs (Mason and Brown 2010). This also relates to recent work that links human capital in determining productivity heterogeneity (see Abowd et al. 2005; Ilmakunnas et al. 2004; Fox and Smeets 2011).

From the internationalisation and trade perspectives, many HGFs are globally oriented and sell overseas. This is consistent with what has been found in the international economics literature, where firms self-select into global markets due to their superior productive efficiency (Greenaway and Kneller 2007). Therefore, it is reasonable to expect that productivity may not only describe a key firm characteristic but potentially explain the nature, driver or even the consequences of high-growth phenomena alongside various other determinants that have already emerged from the HGF literature.

One could also argue that the relationship between HGFs and productivity could be stagnant or negative. For instance, one important determinant of higher productivity is process improvement due to experience accumulation, also commonly known as 'learning by doing'. ${ }^{1}$ The 'Penrose effect' describes precisely this challenge in terms of managerial capabilities and the absorption of technology as being the key binding constraint that can limit firm growth (Penrose 1959). In this regard, a firm can experience inefficiency following a period of rapid expansion. This is due to the inability to adjust managerial and other resources in time to deal with the additional organisational complexities that are typically associated with a period of rapid firm growth.

In a study on Sweden by Daunfeldt et al. (2010), HGFs are defined in terms of their productivity, valueadded, sales and employment growth to determine whether different measures contribute differently to aggregate employment and economic growth. They find that HGFs defined in terms of employment growth over the period 1997-2005 have a small and negative effect on productivity growth, whilst HGFs defined in terms of productivity have an insignificant or even negative effect on employment and sales growth. This, they argue, suggests a short-term trade-off between employment and productivity. In other words, a firm may grow in terms of employment without much efficiency improvements, or experience slower employment growth in favour of capital investments for future efficiency gains. This is echoed in a recent report by the UK Department for Business, Enterprise and Regulatory Reform (BERR) (2008), which notes that HGF status in itself may not necessarily imply high productivity.

The potential economic significance of the causal link between productivity and HGFs and its policy relevance warrants a thorough examination. This paper fills this gap by exploring this relationship in both the manufacturing and services sectors in the United Kingdom, utilising a large firm-level database over the period 2001-2010. More specifically, we ask two related research questions. Firstly, can higher productivity growth lead to HGF status and secondly,

\footnotetext{
${ }^{1}$ In the case of young firms or start-ups, this process of learning by doing may take years to acquire.
} 
does HGF experience help firms achieve faster TFP growth?

By employing an array of measures for TFP across a number of specifications, our overall findings show firstly that on average, firms that exhibit higher productivity growth are more likely to become HGFs and secondly that HGF experience enhances the prospects of higher productivity growth in the future through a number of firm-level and regional economic channels. These results hold across both the manufacturing and services sectors.

The rest of the paper is structured as follows. Section 2 gives an overview of the literature on HGFs and productivity. Section 3 describes the data and measurement issues, followed by Section 4 that discusses the estimation strategy. Section 5 presents the main results on whether higher productivity growth leads to HGF status. Section 6 presents results that show to what extent HGF experience helps firms achieve faster TFP growth. Finally, Section 7 concludes.

\section{The literature on HGFs and productivity}

Since Birch's seminal work (1987) on the identification of HGFs, there has been a significant interest in the characteristics of HGFs both in the academic and policy arena. It is clearly of interest to policy makers across many countries to nurture an adequate environment to sustain and more importantly foster the development of HGFs that create a disproportionally large amount of jobs (Storey 1994). Within a short period, our knowledge has expanded considerably on the antecedents, nature and implications of HGFs. Statistical regularities are emerging from the literature despite the differences in country choice, methods, time periods and HGF definitions (see recent survey by Henrekson and Johansson 2010a). Evidence suggests that HGFs exist in all industries; they grow rapidly and generate a large share of all new jobs, irrespective of the firm population, time period and macroeconomic conditions (Birch 1987; AnyadikeDanes et al. 2009; Henrekson and Johansson 2010a; Kirchhoff 1994). ${ }^{2}$

\footnotetext{
${ }^{2}$ There is less consistency between studies in terms of whether HGFs make a disproportionate contribution to total job growth. The evidence is positive for the USA but not for some other countries, such as Sweden (Davidsson and Delmar 2006).
}

Based on the existing evidence, HGFs can be of all sizes. Whereas small firms are overrepresented in the population of HGFs, large firms can also be important creators of jobs (BERR 2008; Coad et al. 2012). In terms of age, evidence suggests that the majority of HGFs are over 5 years old, although young firms are more likely to be HGFs for the United Kingdom (Anyadike-Danes et al. 2009; Bravo-Biosca 2011). However, when the growth definition shifts from employment growth to value growth, the average age of such firms in the United States is much older with fewer firms being start-ups (Acs et al. 2008).

Many studies have linked other firm characteristics to HGFs. For example, innovation has been considered an important attribute of HGFs (Coad 2009; Mason et al. 2009) as well as a high level of internationalisation (Mason and Brown 2010; Du and Temouri 2010). Parker et al. (2010) study the role of management strategy in sustaining high growth in sales, based on a group of mid-sized UK HGFs. They identify a number of influential strategic and environment factors that explain firm growth patterns and highlight the importance of the dynamic nature of these factors in a changing economic environment. HGFs are also linked to wider economic and social outcomes, such as the growth of other firms in the same locality (Mason et al. 2009) and particularly in industrial clusters (Stam et al. 2009).

\subsection{A gap in the existing HGF literature}

The study of Acs et al. (2008) is one of the few studies that attempt to investigate the role of productivity among fast-growing firms. They show that highimpact firms ${ }^{3}$ in the United States have a large effect on productivity. Based on revenue per employee to measure labour productivity and comparing statistical means between high- and low-impact firms, they generally find that high-impact firms have higher labour productivity than low-impact firms. They also find that the difference in labour productivity between high- and low-impact firms has widened in the United States over time. They argue that productivity is an

\footnotetext{
3 Acs et al. (2008) define high impact as enterprises whose sales have at least doubled over a four-year period and which have an employment growth quantifier (the relationship between its absolute and percentage change) of two or more over the period. The average age of high-impact firms is 25 years old.
} 
important channel through which high-impact firms contribute to the aggregate economy, but this is not directly tested.

Bravo-Biosca $(2010,2011)$ uses industry-level data for 12 OECD countries over the period 2002-2005 to test the relationship between TFP growth and the dynamics of the growth distribution. The latter is proxied by whether firms expand, contract or remain static over a period of time. His results show that the greater the share of firms that remain static, the lower the productivity growth observed. However, his findings also show that the share of both growing and shrinking firms is associated with faster productivity growth. In his study, Europe has a much larger share of static firms, which may be a reason for the regions' lower productivity performance at the aggregate level.

Apart from studies that compare labour productivity levels across firms, there is limited evidence on the causes and consequences of productivity growth on HGF incidence and contribution to overall economic growth. An exception, using UK firm-level data, is Mason et al. (2012) who present static and dynamic decomposition estimates of labour productivity growth changes over the period 1998-2007. They find HGFs to be on average more productive, but that they have a limited contribution to overall industry productivity growth. In addition, a related crosscountry study was undertaken by the OECD (2003) using firm-level data for 10 advanced countries and reveals that new firms contribute more to TFP as they enter with innovative combinations of factors of production and new technologies.

\subsection{Linking productivity and HGFs}

Productivity has stimulated a lot of research across a number of fields including macroeconomics, industrial organisation and international trade (Bartelsman and Doms 2000; Syverson 2011). Over the last three decades, a myriad of studies have increasingly used plant and firm-level data that show large productivity dispersions, even within narrowly defined industries. However, aggregate productivity growth is not only driven by within-firm productivity improvements, but also by effective resource reallocation (see, for example, Baily et al. 1996). This means that production function models can only approximate a much more complex production process (Cuneo and Mairesse 1983). Moreover, it is very challenging to draw causal inference in this line of research, and we know little about the relative importance of the factors that are associated with productivity growth (Bartelsman and Doms 2000).

One of the key reasons that firms display wide productivity level and growth differences is the technology adopted in the production process. Studies that have combined human capital and advanced technology have uncovered particularly interesting findings showing that technology may complement rather than substitute labour skills (Doms et al. 1997), and that this further explains the persistence of productivity (Bartelsman and Doms 2000).

Recently, there is a growing interest in understanding the role that intangible assets play in driving firm growth. Attempts to link intangible assets to productivity growth in the United Kingdom (see, for example, Riley et al. 2011; Dal Borgo et al. 2012) show that intangible assets have a positive and significant association with productivity, and firms with a higher proportion of intangible assets are more likely to be highly productive. This presents another measurement unit to complement our understanding of the sources of firm growth beyond the known tangible factors of production, such as R\&D investment, advanced technology and facilities (Lichtenberg and Siegel 1991; Van Biesebroeck 2003).

Management practices can also lead to productivity differences between firms, ceteris paribus. However, a difficulty arises in the measurement of management strategies. Equally challenging is to disentangle the causality in the relationship between management practices and productivity performance (Syverson 2011). In this regard, the evidence is limited and the few available studies are mostly based on relatively small surveys. For example, Bloom and Van Reenen (2007) find that family-owned firms tend to have inferior management practices that in turn are associated with a declining TFP performance. Recent work has also used more reliable proxies to measure management practice in the area of human resource management (see, for example, Edward and Lazear 2000) and organisational strategies (Boning et al. 2007). Yet, Parker et al. (2010) studying how management strategy affects firm growth patterns among mid-sized UK HGFs argue that the dynamic nature of the management strategies is the key to growth persistence, whilst best practice strategies are unlikely to foster firm growth. 
Another extensively studied factor that relates to productivity is the international exposure of firms. Productivity comparisons have been undertaken across firms according to the different levels of engagement in international markets (Helpman et al. 2004; Melitz 2003; Wagner 2007), across various industries (Harris and Robinson 2003) and country of foreign ownership (Criscuolo and Martin 2007). They essentially show that productivity differences are a key determinant of firm heterogeneity, and if firm productivity is one of the main channels for aggregate economic growth, then policy makers are advised to take this into account when formulating certain initiatives. $^{4}$

The international business and entrepreneurship literature also offers a plethora of evidence on the performance effects of internationalisation (Driffield et al. 2010), R\&D and innovation (Roper et al. 2008). A recent study by Ganotakis and Love (2012) uses survey responses of UK technology-based firms to investigate how the characteristics and experience of the entrepreneurial founding team affect the export orientation and subsequent performance of the businesses they establish, whilst allowing for the mutually reinforcing relationship between exporting and productivity. They find that the set of management skills (e.g. commercial experience) needed to enter foreign markets via exports is different from the skills required in succeeding in export markets (e.g. education). They also find that the more productive firms self-select into export markets and that exporting leads to further firm productivity improvements. Therefore, it may not be surprising to find that multinational firms as well as exporters are more likely to be associated with HGF incidence. Related to this, the literature also provides evidence that the organic growth of a firm or growth via merger and acquisition activity can also be a source of productivity growth (Deschryvere 2008; Lockett et al. 2011).

\footnotetext{
$\overline{4}$ The entry of multinational firms and export activities has been shown to have an impact on domestic firms' output, employment and efficiency through enhanced competition, technology diffusion, export market access and training of workers. There is a large body of empirical evidence that points to a robust correlation between multinationality, exporting and firm performance (see, for example, Bernard and Jensen 1999; Harris and Li 2007; Driffield et al. 2008), and most of the work has shown that exporters and foreign-owned firms generally have a higher performance.
}

As well as the above, the literature suggests that firm growth rates may also be affected by a range of other factors including the reliance on internal finance (Oliveira and Fortunato 2006), on leverage (Lang et al. 1996; Huynh and Petrunia 2010), and on the external sources of finance (Du and Girma 2007). This stems from the detrimental effects of financial constraints, due to information asymmetries and agency problems, on firm investment decisions (Fazzari et al. 1988) and inventory investment (Carpenter et al. 1994). These constrained choices reflect distortions of resource allocation that may reduce productivity (Chen and Guariglia 2013).

Finally, given the multifaceted nature of HGFs, the identification of local and institutional factors impacting on the environment that gives rise to HGFs has not been explored in any great detail, despite the significant investments by sub-national local authorities and organisations to make regions more attractive to businesses. There are a few studies in the regional science and institutional economics literature that attempt to explain some of these drivers, where local and institutional factors may either induce or hinder firm growth. For example, Hart and Mcguinness (2003) show that differences across a wide set of regional factors or the external business environment can explain small firm growth for UK manufacturing and services industries. A recent study by Henrekson and Johansson (2010b) makes the case for how a number of complementary policies can create a framework that can improve the conditions for HGFs to flourish.

\section{Data}

The data for our analysis are drawn from FAME that is a commercially available dataset compiled by Jordan's, distributed by Bureau van Dijk and sourced from Companies House. ${ }^{5}$ The dataset provides information on company profiles, profit and loss accounts, balance sheets, ownership and industry affiliations. Annual regional-level data at NUTS 2 level are drawn from Eurostat and merged with the firm-level dataset.

After isolating firms that report information on the key variables used in our analysis, we end up with

\footnotetext{
5 Additional information about the data source can be found in the online appendix.
} 
183,024 firm-year observations for 26,313 firms, covering the time period of 2001-2010. It is important to note that the panel of firms is unbalanced and most firms are not observed for the entire 10-year period. We have also only included firms for which we have unconsolidated accounts, as they represent the domestic activities of firms and not their operations worldwide or an aggregate in the case of owning other companies at home. As this is an unbalanced panel, the number of observations differs across years and ranges from 12,000 to $20,000 .^{6}$

Unlike many previous studies that use consumer price indices to deflate the industrial outputs and other monetary variables, we deflate our financial variables using 4-digit producer price indices (PPI) for the manufacturing industries and service price indices (SPPI) for service industries sourced from the UK Office of National Statistics and EconStats. ${ }^{7}$ This approach helps us to get a more accurate account of the production elements for productivity estimation purposes.

In this paper, we rely on firm sales growth to define high-growth incidence, compared with the highgrowth literature that tends to adopt either employment or value-added growth as the high-growth criteria. Employment adjustment is usually slower during productivity shocks and hence may not reflect contemporary firm performance changes. From a theoretical point of view, the link between employment growth adjustment and TFP growth seems much more debatable in the current productivity literature. There are reasons to believe that employment growth and size patterns have more to do with industrial characteristics than firm performance variations. Therefore, we adopt the compounding annual growth calculation consistent with the Eurostat-OECD

\footnotetext{
${ }^{6}$ For each year between the period 2001 and 2009, the number of observations is around $9-11 \%$ of the total. The year 2010 captures fewer firms, namely $6.7 \%$ of the total observations, which can be due to firm exits, late reporting of accounts and fewer firms reporting key variables used in this analysis. This is a common characteristic with commercially available datasets that update their datasets with a lag. The exact panel structure of the data in terms of time period and industrial sectors can be seen in the Appendix Tables 1 and 2 in Du et al. (2013), which is a related research report that uses the same data. The Web link to this report is http://www.nesta.org.uk/publications/highgrowth-firms-and-productivity-evidence-united-kingdom.

7 For a more detailed description on the deflators used, see the online appendix.
}

definition (2007), which defines a firm as a HGF if it grows at an average annual growth in sales of at least $20 \%$ over a 3 -year period and employs 10 or more employees at the start of the growth period. ${ }^{8,9}$ Table 1 shows the distribution of the incidence of HGFs across 2-digit industries. We also provide HGF status calculations using employment as an alternative to sales for comparison purposes.

As shown in Table 1, the estimate of the HGF incidence for all sectors is around $11.6 \%$ based on sales growth rate and $4.6 \%$ based on employment growth. The estimates of HGF incidence using sales are usually higher than those based on employment figures, which is common in the literature. Compared with the well-known HGF figure of around $6 \%$ based on employment for the United Kingdom (AnyadikeDanes et al. 2009), our figure is slightly lower, which could be due to the sample bias towards large firms. The industry differences in the HGF incidence are quite evident. Some sectors show above-average HGF incidence, such as Office Machinery, Communication Equipment and Recycling for Manufacturing, and Post and Telecommunications, Financial Intermediation, Real Estate Activity, and Research and Development. Interestingly, the HGF incidence is much higher in service industries $(13 \%)$ than the manufacturing industries $(8.89 \%)$, which is contrary to the historically held view of higher productivity growth in manufacturing (Baumol 1967).

There is currently an active discussion about the low level of productivity growth since the start of the recession in the United Kingdom (Dale 2011). We have therefore compared HGFs before and during the recession. Table 1 also shows the number of HGF incidences in various sectors overall, before the recession in 2006 and during the recession in 2009. Overall, a clear drop in the number of HGFs can be observed. Whereas $16.3 \%$ of firms experience high growth at the end of 2006, only $6.59 \%$ can be observed in this category in 2009-a drop of $10 \%$

\footnotetext{
8 Based on a synthesis of 19 studies, Henrekson and Johansson (2010a) note that there is no general agreement on the definition of HGFs. Definitions vary in terms of the following: choice of growth indicator (e.g. employment, sales and profits), measurement of growth, length of time period over which growth is measured and whether growth through acquisition is included or just organic growth (Delmar et al. 2003).

${ }^{9}$ For a description and distribution of HGF incidence across 2-digit industries, see the online appendix.
} 


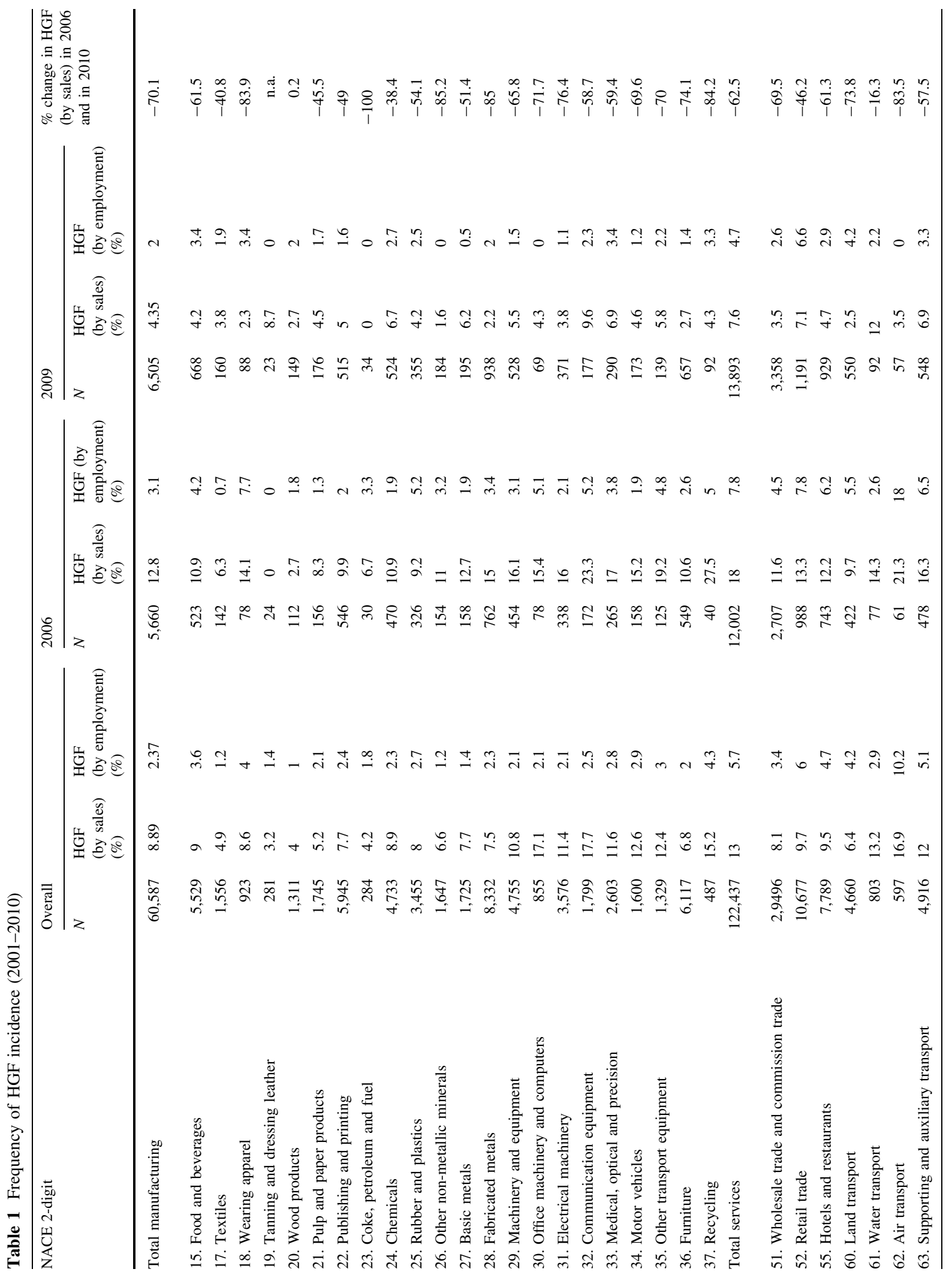




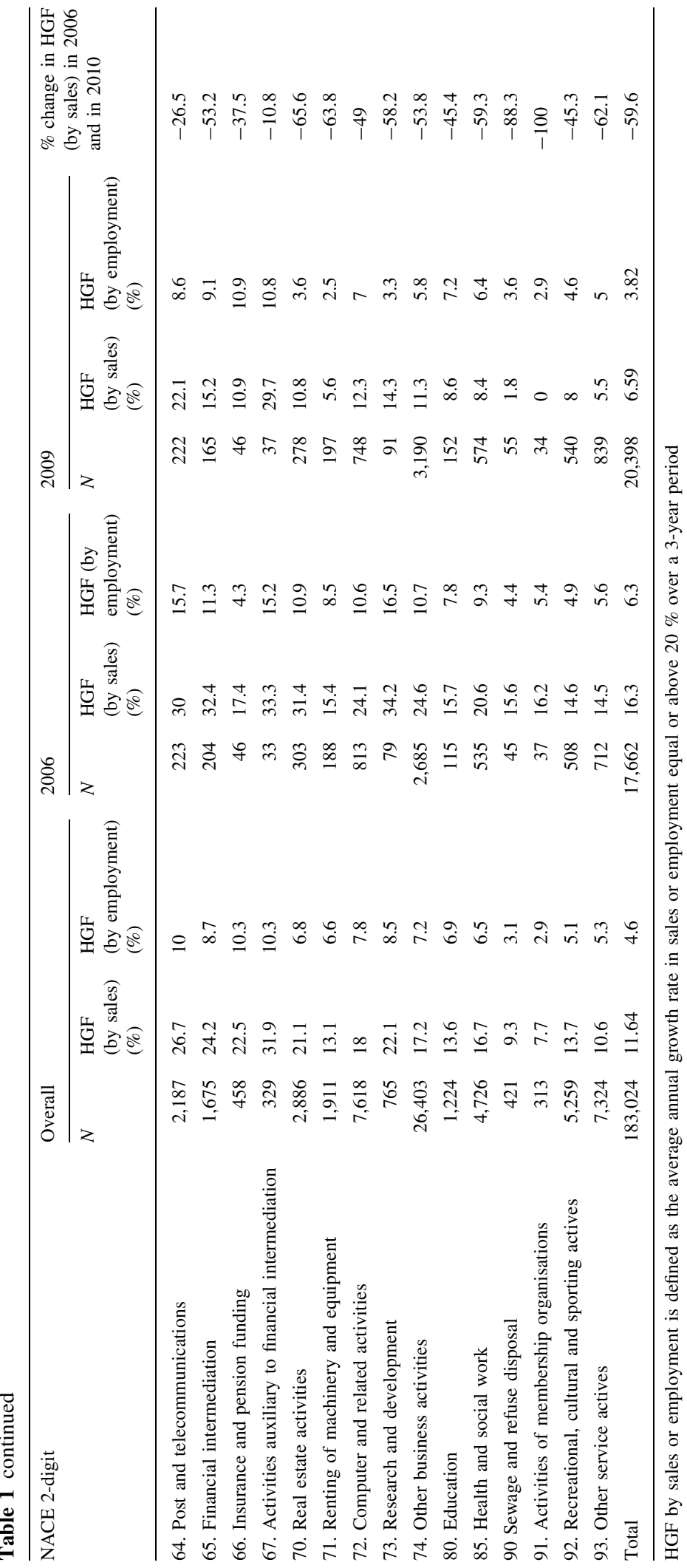


points. By comparing industries more closely, one observes that the majority of the sectors have experienced a reduction in HGF incidence, most notably in the wearing apparel (NACE 18) and activities of membership organisation (NACE 91), water transport (NACE 61) and activities auxiliary to financial intermediation (NACE 67). These results are largely in line with what has been found in recent studies, which show a decline in both new firms formation and HGF incidence during the crisis period (AnyadikeDanes and Hart 2012).

Table 2 provides descriptive statistics of the variables used in our subsequent analysis. As our HGF definition is in terms of sales growth, the data show a clear pattern that HGFs are smaller and younger, in both the manufacturing and service sectors. They tend to have slightly higher levels of intangible assets, pay higher wages, are slightly more experienced internationally and significantly more productive than their counterparts. At the same time, large standard deviations indicate that there is great heterogeneity in each group, which suggests that large as well as older firms can be HGFs. This is consistent with the evidence shown in the literature (Henrekson and Johansson 2010a; Acs et al. 2008).

\section{Framework and research design}

In the search for a two-way relationship between productivity growth and HGFs, we take a two-step approach. Step 1 focuses on the role of productivity growth in determining HGF status, and Step 2 examines how HGF experience affects subsequent TFP growth.

\subsection{Step 1}

To examine the determinants of HGF incidence, we specify a probability function of a HGF incidence. The main aim is to test whether firm productivity growth plays a significant role in determining this probability. Our baseline model takes the following form:

$$
\begin{aligned}
\mathrm{HGF}_{i t}^{*}= & \alpha+\beta^{\prime} g t f p_{i t-1}+\chi^{\prime} Z_{i t-1}+\kappa^{\prime} R_{k t-1} \\
& +v_{t}+v_{j}+\varepsilon_{i t}
\end{aligned}
$$

where $\mathrm{HGF}_{i t}^{*}$ is a latent variable, linking to a binary variable HGF, which takes the value of 1 if firm $i$ is a HGF at time $t$, and takes the value of 0 otherwise. It is noteworthy that HGF is not an entry indicator. Our main interest is how TFP growth in the previous year, $g t f p_{t-1}$, affects the probability of HGF status. The vector $Z_{i t-1}$ captures a set of control variables that are important in explaining HGF incidence or firm growth in general. These variables include firm age, size, cash holdings, intangible assets, average wage and international activities.

Firm size is measured by the log of total employment. Cash holdings and intangible assets are both normalised by the firm's total fixed assets. Consistent with the literature reviewed earlier, intangible assets are included as an indicator of wider innovative capacity. It includes goodwill, intellectual property rights, patents, trademarks, $R \& D$ investment, website domain names and typically long-term investment that may relate to a firm's innovative efforts. Some argue that intangible assets as a variable have the advantage of being continuous and derived from administrative data sources rather than from surveys (Bartoloni 2013), but we do not know the exact composition of this variable because of the discretion of what firms decide to report as intangible assets.

A firm's financial liquidity is captured by the amount of cash holding. The finance literature argues that large cash holdings can be seen to negatively affect a firm, especially when the interests and incentives of managers and shareholders are in conflict over the optimal size of the firm and the payment of dividends to shareholders. In other words, large cash holdings may be a sign of managers not being able to spot profitable investment opportunities and at the same time neither distributing these to shareholders (Jensen 1987). In the current uncertain economic climate, firms also tend to be holding large amounts of cash as an insurance policy against a sudden unpredictable event, such as the Euro depreciating.

The average wage is measured by dividing the total wage bill by the number of workers employed. Due to a lack of detailed information on employee qualifications in FAME, we use average wages as a proxy for the average level of human capital in the firm, which is common in the firm-level literature (Wagner 2012).

A firm's international activities are captured by exports and outward FDI. We generate a state variable (MNE) to indicate a multinational firm, taking the value of 1 if a firm has any outward FDI at any time during the observation period, which means that this variable is time-invariant. It is well known that the 


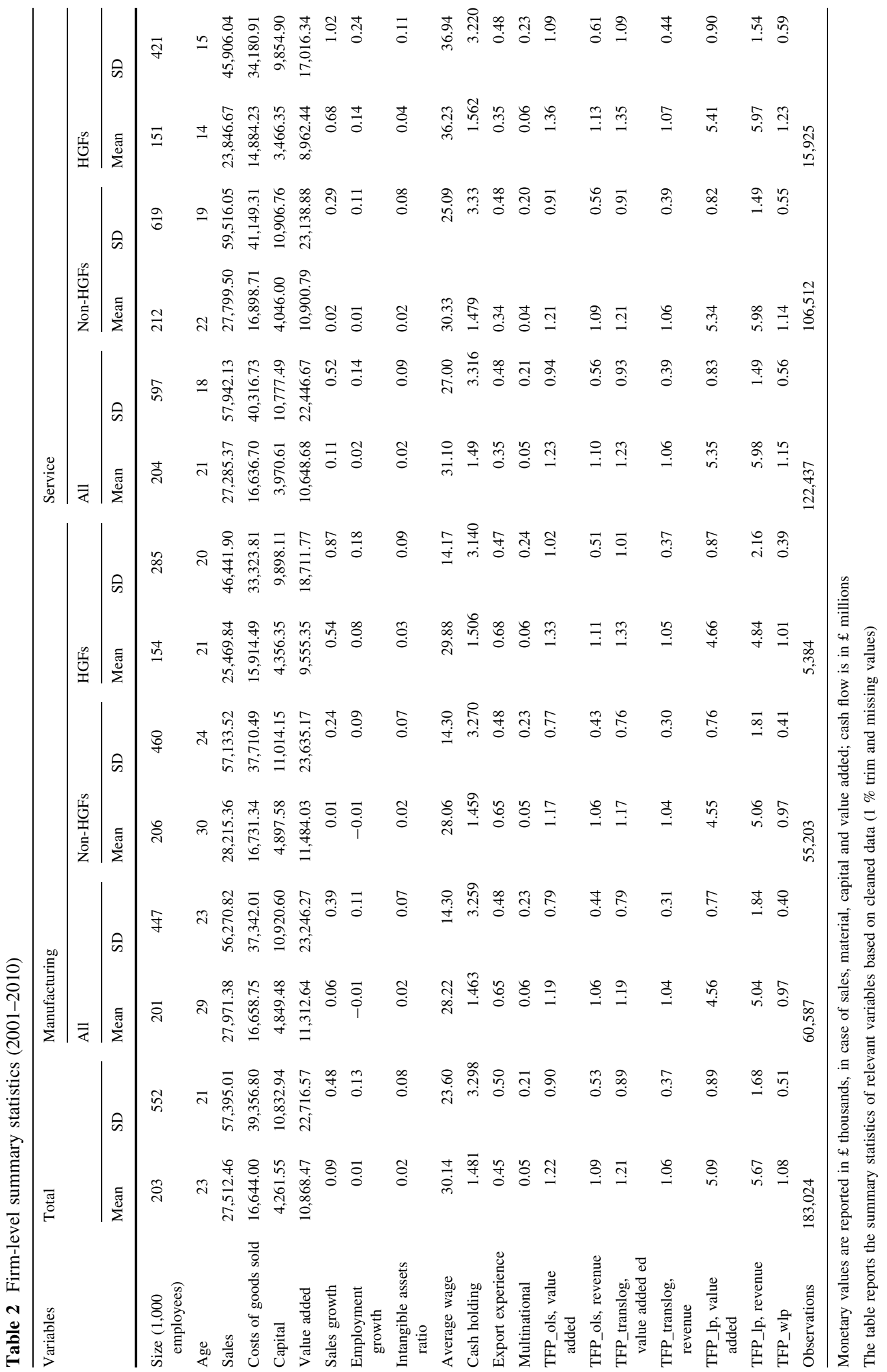


records of export volume are limited in FAME. To remedy this, we construct a dummy variable called export experience (expexpr) that takes a value of 1 if a firm is observed to export in any previous period. The gain of having a stable measure of export activities comes at the expense of losing the volume of export activities.

The vector $R_{k, t-1}$ is a vector of regional characteristics lagged one period, including GDP growth, unemployment levels, infrastructure (proxied by the volume of air traffic) and the number of patents registered at the NUTS 2 regional levels to capture the environmental factors that shape HGF incidence, and controls for the differences in effects they may have for firms in manufacturing and service sectors. Finally, the error term is made up of a time-specific component $\left(v_{t}\right)$, a 2-digit industry-specific component $\left(v_{j}\right)$ and an idiosyncratic error term $\varepsilon_{i t}{ }^{10}$

Potential endogeneity can arise in Eq. (1), where unobserved firm heterogeneity may lead to an increase in sales growth that is at the same time correlated with productivity growth. These unobserved characteristics might be exceptional leadership that drives firms to be more productive, whilst also leading to high sales growth (through making visionary strategies or beneficial business networks). Dealing with unobserved heterogeneity is always challenging, and this is particularly the case when using nonlinear models. In this paper, we utilise two measures to address this issue. As a baseline investigation, we estimate a pooled static probit model in which all explanatory variables, except MNE, are lagged by 1 year to help mitigate potential endogeneity, and correct heteroskedastic standard errors by clustering at the individual firm level. The regressions are estimated separately for the manufacturing and service sectors. We also separately look at new firms (no older than 5 years) and incumbents (older than 5 years), as the impediments to firm growth at various stages may be quite different. We also seek to deal with firm additive unobserved heterogeneity that may cause endogeneity by applying a dynamic panel model approach by Wooldridge (2005) and obtain qualitatively comparable results.

\footnotetext{
${ }^{10}$ For a summary of variable definitions and sources, see the online appendix.
}

\subsection{Step 2}

In the second step, we investigate the productivity implication of the high-growth phenomenon. Does HGF experience enhance productivity? If it does, how does it happen? To associate HGF experience with productivity growth, we adopt a quantile regression approach to investigate the role of HGF experience in enhancing productivity growth along the TFP growth distribution (Koenker and Bassett 1978). Thus, assuming the population regression takes on the following form:

$$
\begin{aligned}
g t f p_{i t}= & \alpha+\beta^{\prime} \text { HGF_EXP }{ }_{i}+\chi^{\prime} Z_{i t-1}+\kappa^{\prime} R_{k t-1} \\
& +v_{t}+v_{j}+\varepsilon_{i t}
\end{aligned}
$$

where the variables are defined in the same way as in Eq. (1). The quantile regression model can be written as:

$$
\begin{aligned}
& g t f p_{i t}=\alpha+\beta^{\prime} \mathrm{HGF}_{2} \mathrm{EXP}_{i}+\chi^{\prime} Z_{i t-1}+\kappa^{\prime} R_{k t-1}+v_{t} \\
& \quad+v_{j}+\varepsilon_{i t} ; \\
& \text { Quant }_{\theta}\left(g t f p_{i t} \mid \mathrm{HGF}_{\mathrm{EXP}}, Z_{i t-1}, R_{k t-1}, v_{t}, v_{j}\right) \\
& =\alpha_{\theta}+\beta_{\theta}^{\prime} \mathrm{HGF}_{-} \mathrm{EXP}_{i}+\chi_{\theta}^{\prime} Z_{i t-1}+\kappa_{\theta}^{\prime} R_{k t-1}+v_{t}+v_{j}
\end{aligned}
$$

where Quant $_{\theta}\left(g t f p_{i t} \mid \mathrm{HGF}_{\mathrm{N}} \mathrm{EXP}_{i}, Z_{i t-1}\right)$ denotes the conditional quantile of gtfp. The distribution of the error term $\varepsilon_{\theta}$ is left unspecified, making the estimation method semi-parametric. By increasing $\theta$ from 0 to 1 , we can trace the effects of HGF experience on the entire distribution of TFP growth, conditional on the set of control variables. In addition, we can focus our attention on specific parts of the TFP growth distribution and identify where in the distribution HGF experience exerts the greatest impact.

We specify a dichotomous HGF experience variable $\left(\mathrm{HGF}_{\mathrm{CXP}}\right)$ to capture what the consequences of HGF experience are. We define previous HGF_EXP as a dummy variable according to its high-growth incidence variable, HGF, generated in Step I. Thus, HGF_EXP takes the value 1 if HGF takes value 1 in any of the previous periods. This allows any previous HGF experience to affect productivity, even if it happened in the begining of the sample period, as knowledge accumulates and firms may take time to learn. Testing whether this dummy is statistically significant in affecting TFP growth offers evidence for the existence of a HGF experience, controlling for other factors and firm unobserved heterogeneity. We correct heteroskedastic 
standard errors by clustering at the individual firm level in the baseline least squares estimation.

\subsection{TFP estimation and sensitivity}

Conceptually, productivity captures changes in output after controlling for differences in inputs. However, the measurement of productivity is not a trivial task, as problems often arise with measurement error in inputs and simultaneity in production functions. As a result, the debate on the most appropriate method is extensive and ongoing (cf., Bartelsman and Dhrymes 1998; Griliches and Mairesse 1995; Olley and Pakes 1996; Levinsohn and Petrin, 2003; Van Biesebroeck 2003; Wooldridge 2009; Petrin and Levinsohn 2012).

In this paper, we employ four widely used methodologies to estimate TFP. They fall into three statistical strands: parametric, semi-parametric and GMM. Nonparametric approaches are not considered because they tend to be more sensitive to measurement error. We start by estimating productivity using a Cobb-Douglas production function, using least squares and correcting for firm individual heteroskedasticity (LS). By relaxing the assumption of constant returns to scale and allowing for a more flexible functional form, we then estimate a translog production function (TL). Following this, we introduce the Levinsohn and Petrin (2003) (LP) and Wooldridge (2009) (WLP) estimators to control for endogenous inputs and measurement error. All estimations are conducted in each of the NACE 2-digit industries separately. ${ }^{11}$

Based on an informal test using the Spearman's rank correlation coefficients between labour productivity (the log of total revenue per employee or value added per employee) and each of the 2-digit industryspecific TFP estimates, following Girma and Gong (2008), the estimates obtained by LS, TL and LP are positively and highly correlated with labour productivity and statistically significant at the $1 \%$ level, whilst the rank correlation between labour productivity and WLP estimates is relatively low but it still stays reasonable. Given these findings, we prefer the LP estimates due to their statistical properties discussed above, although we do not expect the differences between them to be significant.

\footnotetext{
${ }^{11}$ More details about the estimation procedures are provided in the online appendix.
}

\section{Does higher productivity growth lead to high- growth incidence?}

The determinants of HGF incidence are reported in Tables 3 and 4 for the manufacturing and service sectors, respectively. Two sets of static model estimation results are discussed below, namely a standard probit model and a random effects panel probit model. The estimates are also reported for new firms (no older than 5 years) and incumbents (older than 5 years).

The first result to emphasise is that across model specifications, we find highly statistically significant estimates of the coefficients on TFP growth across both sectors, and for both new firms and incumbents. This is strong evidence that firm TFP growth increases the probability of a firm entering a high-growth period, ceteris paribus. The magnitudes of the TFP growth coefficients yield interesting insights. After specifying individual unobserved heterogeneity by the random effects panel estimator, the TFP growth coefficient is larger for incumbent firms than for new firms in the manufacturing sector, suggesting that incumbents are more likely to reach HGF status with productivity improvements. The opposite is true for the service sector, although the marginal effects between new firms and incumbents are small. This implies that the learning curve is likely to be steeper for incumbent manufacturing firms, whereas it is steeper for young service firms. In other words, it may take longer to accumulate knowledge, experience and the capability to identify productivity improvements (Syverson 2011).

We control for a number of variables drawn from the literature, and they confirm the qualitative results found therein. Firm age shows a negative sign across all specifications. This suggests that firms are more likely to experience high growth at an early stage of their existence. Whereas size has a significantly negative impact on HGF incidence in the manufacturing sector, the coefficients are mostly positive and marginally significant in the service sector. This suggests that HGFs are on average smaller in the manufacturing sector, but not in the service sector. This trend is more obvious for newly established firms than for incumbents, consistent with the existing evidence (Anyadike-Danes et al. 2009; Bravo-Biosca 2011). Our results also support the findings by BravoBiosca (2011) showing that firm age is more important in explaining HGF incidence compared with firm size. 
Table 3 Is TFP growth a determinant of HGF incidence? (manufacturing sector)

\begin{tabular}{|c|c|c|c|c|c|c|}
\hline \multirow[t]{2}{*}{ Variables } & \multicolumn{3}{|c|}{ Static probit model } & \multicolumn{3}{|c|}{ Random effects panel probit model } \\
\hline & All firms & $\begin{array}{l}\text { New firm, } \\
\leq 5 \text { years }\end{array}$ & $\begin{array}{l}\text { Incumbents, } \\
>5 \text { years }\end{array}$ & All firms & $\begin{array}{l}\text { New firm, } \\
\leq 5 \text { years }\end{array}$ & $\begin{array}{l}\text { Incumbents, } \\
>5 \text { years }\end{array}$ \\
\hline \multicolumn{7}{|l|}{ Productivity } \\
\hline $\begin{array}{l}\text { TFP } \\
\text { growth }_{i t-1}\end{array}$ & $\begin{array}{l}0.144 * * * \\
(0.00724)\end{array}$ & $\begin{array}{l}0.230 * * * \\
(0.0302)\end{array}$ & $\begin{array}{l}0.132 * * * \\
(0.00736)\end{array}$ & $\begin{array}{l}1.167 * * * \\
(0.0587)\end{array}$ & $\begin{array}{l}0.742 * * * \\
(0.180)\end{array}$ & $\begin{array}{l}1.198^{* * *} \\
(0.0666)\end{array}$ \\
\hline \multicolumn{7}{|c|}{ Firm characteristics } \\
\hline $\mathrm{Age}_{t}$ & $\begin{array}{c}-0.00135 * * * \\
(0.000135)\end{array}$ & $\begin{array}{c}-0.0373 * * * \\
(0.0106)\end{array}$ & $\begin{array}{c}-0.00104 * * * \\
(0.000129)\end{array}$ & $\begin{array}{c}-0.0235^{* * *} \\
(0.00200)\end{array}$ & $\begin{array}{c}-0.621 * * * \\
(0.0883)\end{array}$ & $\begin{array}{c}-0.0183 * * * \\
(0.00197)\end{array}$ \\
\hline Size $_{t-1}$ & $\begin{array}{c}-0.0347 * * * \\
(0.0088)\end{array}$ & $\begin{array}{c}-0.21 * * * \\
(0.0661)\end{array}$ & $\begin{array}{c}-0.0287 * * * \\
(0.0085)\end{array}$ & $\begin{array}{c}-0.43 * * * \\
(0.113)\end{array}$ & $\begin{array}{c}-1.99 * * * \\
(0.735)\end{array}$ & $\begin{array}{c}-0.39 * * * \\
(0.114)\end{array}$ \\
\hline $\begin{array}{l}\text { Intangible } \\
\text { assets } \\
\text { ratio }_{t-1}\end{array}$ & $\begin{array}{l}0.104 * * * \\
(0.0263)\end{array}$ & $\begin{array}{c}0.0792 \\
(0.0808)\end{array}$ & $\begin{array}{l}0.0830 * * * \\
(0.0305)\end{array}$ & $\begin{array}{l}1.537 * * * \\
(0.333)\end{array}$ & $\begin{array}{c}1.119 \\
(0.950)\end{array}$ & $\begin{array}{l}1.257 * * * \\
(0.390)\end{array}$ \\
\hline $\begin{array}{l}\text { Average } \\
\text { wage }_{t-1}\end{array}$ & $\begin{array}{l}0.000711^{* * * *} \\
(0.000230)\end{array}$ & $\begin{array}{c}0.000284 \\
(0.000515)\end{array}$ & $\begin{array}{l}0.000848 * * * \\
(0.000194)\end{array}$ & $\begin{array}{l}0.00641 * * * \\
(0.00190)\end{array}$ & $\begin{array}{c}0.00322 \\
(0.00557)\end{array}$ & $\begin{array}{l}0.00864 * * * \\
(0.00207)\end{array}$ \\
\hline Cash flow $_{t-1}$ & $\begin{array}{r}-0.0002 \\
(0.0010)\end{array}$ & $\begin{array}{c}0.0008 \\
(0.0061)\end{array}$ & $\begin{array}{c}-0.00063 \\
(0.0010)\end{array}$ & $\begin{array}{c}-0.0208 * \\
(0.0108)\end{array}$ & $\begin{array}{r}-0.0405 \\
(0.0598)\end{array}$ & $\begin{array}{c}-0.0216^{*} \\
(0.0113)\end{array}$ \\
\hline Export $_{t-1}$ & $\begin{array}{c}0.00484 \\
(0.00514)\end{array}$ & $\begin{array}{c}-0.0549 * * \\
(0.0259)\end{array}$ & $\begin{array}{l}0.00843 * \\
(0.00509)\end{array}$ & $\begin{array}{c}0.0889 \\
(0.0748)\end{array}$ & $\begin{array}{c}-0.476^{*} \\
(0.280)\end{array}$ & $\begin{array}{c}0.155^{* *} \\
(0.0786)\end{array}$ \\
\hline MNE & $\begin{array}{c}0.00852 \\
(0.0118)\end{array}$ & $\begin{array}{c}0.00452 \\
(0.0715)\end{array}$ & $\begin{array}{c}0.00858 \\
(0.0114)\end{array}$ & $\begin{array}{c}0.244 \\
(0.154)\end{array}$ & $\begin{array}{c}0.106 \\
(0.772)\end{array}$ & $\begin{array}{c}0.225 \\
(0.155)\end{array}$ \\
\hline Observations & 32,045 & 2,074 & 29,965 & 32,045 & 2,080 & 29,965 \\
\hline
\end{tabular}

All regressions include the NUTS 2 regional-level variables, including unemployment rate, air traffic, GDP growth, and patent counts, year dummy and NACE 2-digit industrial sector dummies

Marginal effects are reported in the table and robust standard errors in parentheses, *** $p<0.01 ; * * p<0.05 ; * p<0.1$

This is the case for both the service and manufacturing sector.

Firms with more intangible assets on average have a higher probability of reaching HGF status across both sectors. This is broadly in line with research on HGFs, innovation and intangible assets (Mason et al. 2009). Moreover, through analysing firms of different ages, we find that the intangible assets effects are mainly statistically significant among incumbents, rather than among new firms. This may suggest that it takes time to acquire intangible assets, especially when it involves aspects such as $\mathrm{R} \& \mathrm{D}$, brand development and other expenses with a long-term effect. Therefore, the accumulation of several key components of intangible assets may require substantial investment in the early stages of a firm, which may also sustain firm growth potential.

More interestingly, the effect of intangible assets is negative and significant for young firms whilst incumbents enjoy positive effects in the service sector.
On the one hand, this suggests that the accumulation of the key components of intangible assets, such as R\&D, brand development and goodwill, take time to establish, especially in the service sector where customers would in general trust the service provided by a firm with a longer history and better reputation $(\mathrm{Li}$ and Prescott 2009). On the other hand, once a firm manages to survive in the market for more than 5 years, a further investment in intangible assets helps to boost the company's growth and this impact is much stronger in the service sector than in the manufacturing sector.

Average wage appears to be associated with a higher probability of achieving HGF status. Assuming average wage indicates labour quality in a competitive labour market, this result then suggests that labour quality improves firm growth perspectives. Further, we find labour quality to be an important factor for the service sector overall and more so for new service firms than incumbents. In contrast, it is important 
Table 4 Is TFP growth a determinant of HGF incidence? (service sector)

\begin{tabular}{|c|c|c|c|c|c|c|}
\hline \multirow[t]{2}{*}{ Variables } & \multicolumn{3}{|c|}{ Static probit model } & \multicolumn{3}{|c|}{ Random effects panel probit model } \\
\hline & All firms & $\begin{array}{l}\text { New firm, } \\
\leq 5 \text { years }\end{array}$ & $\begin{array}{l}\text { Incumbents, } \\
>5 \text { years }\end{array}$ & All firms & $\begin{array}{l}\text { New firm, } \\
\leq 5 \text { years }\end{array}$ & $\begin{array}{l}\text { Incumbents, } \\
>5 \text { years }\end{array}$ \\
\hline \multicolumn{7}{|l|}{ Productivity } \\
\hline TFP growth $_{i t-1}$ & $\begin{array}{l}0.233 * * * \\
(0.00627)\end{array}$ & $\begin{array}{l}0.392 * * * \\
(0.0243)\end{array}$ & $\begin{array}{l}0.206 * * * \\
(0.00586)\end{array}$ & $\begin{array}{l}1.760 * * * \\
(0.0334)\end{array}$ & $\begin{array}{l}1.956 * * * \\
(0.110)\end{array}$ & $\begin{array}{l}1.822 * * * \\
(0.0400)\end{array}$ \\
\hline \multicolumn{7}{|c|}{ Firm characteristics } \\
\hline $\operatorname{Age}_{t}$ & $\begin{array}{c}-0.0027 * * * \\
(0.000161)\end{array}$ & $\begin{array}{c}-0.0398 * * * \\
(0.00664)\end{array}$ & $\begin{array}{c}-0.0016^{* * *} \\
(0.000129)\end{array}$ & $\begin{array}{c}-0.0338 * * * \\
(0.00137)\end{array}$ & $\begin{array}{c}-0.473 * * * \\
(0.0418)\end{array}$ & $\begin{array}{c}-0.0236 * * * \\
(0.00136)\end{array}$ \\
\hline Size $_{t-1}$ & $\begin{array}{l}0.0026 \\
(0.00324)\end{array}$ & $\begin{array}{r}-0.0205 \\
(0.0205)\end{array}$ & $\begin{array}{l}0.00332 \\
(0.0028)\end{array}$ & $\begin{array}{l}0.0661 * * \\
(0.0325)\end{array}$ & $\begin{array}{r}-0.122 \\
(0.145)\end{array}$ & $\begin{array}{l}0.0644 * \\
(0.034)\end{array}$ \\
\hline $\begin{array}{l}\text { Intangible assets } \\
\text { ratio }_{t-1}\end{array}$ & $\begin{array}{l}0.0660 * * * \\
(0.0138)\end{array}$ & $\begin{array}{c}-0.112 * * \\
(0.0447)\end{array}$ & $\begin{array}{l}0.0615 * * * \\
(0.0149)\end{array}$ & $\begin{array}{l}0.876^{* * *} \\
(0.133)\end{array}$ & $\begin{array}{c}-0.740 * * \\
(0.319)\end{array}$ & $\begin{array}{l}0.859 * * * \\
(0.168)\end{array}$ \\
\hline Average wage $_{t-1}$ & $\begin{array}{l}0.00041 * * * \\
(0.00008)\end{array}$ & $\begin{array}{l}0.00121 * * * \\
(0.000270)\end{array}$ & $\begin{array}{l}0.00031 * * * \\
(0.00007)\end{array}$ & $\begin{array}{l}0.00374 * * * \\
(0.000404)\end{array}$ & $\begin{array}{l}0.00755^{* * *} \\
(0.00152)\end{array}$ & $\begin{array}{l}0.00371 * * * \\
(0.000426)\end{array}$ \\
\hline Cash flow $t-1$ & $\begin{array}{c}-0.0013 * * \\
(0.0005)\end{array}$ & $\begin{array}{c}0.0013 \\
(0.0031)\end{array}$ & $\begin{array}{c}-0.0013 * * * \\
(0.00045)\end{array}$ & $\begin{array}{c}-0.019 * * * \\
(0.0045)\end{array}$ & $\begin{array}{c}0.007 \\
(0.019)\end{array}$ & $\begin{array}{c}-0.002 * * * \\
(0.0048)\end{array}$ \\
\hline Export $_{t-1}$ & $\begin{array}{c}0.00547 \\
(0.00340)\end{array}$ & $\begin{array}{r}-0.0172 \\
(0.0171)\end{array}$ & $\begin{array}{l}0.00962 * * * \\
(0.00320)\end{array}$ & $\begin{array}{c}0.0616 \\
(0.0376)\end{array}$ & $\begin{array}{r}-0.169 \\
(0.130)\end{array}$ & $\begin{array}{l}0.122 * * * \\
(0.0398)\end{array}$ \\
\hline MNE & $\begin{array}{l}0.0254 * * * \\
(0.00804)\end{array}$ & $\begin{array}{l}0.111 * * \\
(0.0470)\end{array}$ & $\begin{array}{l}0.0210 * * * \\
(0.00727)\end{array}$ & $\begin{array}{l}0.358 * * * \\
(0.0788)\end{array}$ & $\begin{array}{l}1.069 * * * \\
(0.326)\end{array}$ & $\begin{array}{l}0.325 * * * \\
(0.0807)\end{array}$ \\
\hline Observations & 78,588 & 7,999 & 70,589 & 78,588 & 7,999 & 70,589 \\
\hline
\end{tabular}

All regressions include the NUTS 2 regional-level variables, including unemployment rate, air traffic, GDP growth, and patent counts, year dummy and NACE 2-digit industrial sector dummies

Marginal effects are reported in the table, and robust standard errors in parentheses, *** $p<0.01 ; * * p<0.05 ; * p<0.1$

mainly for incumbents in the manufacturing sector and not for new firms. This is consistent with the current understanding that service sector firms, although labour-intensive, rely heavily on the quality of the service offered to consumers, particularly at the beginning of the life cycle when firms are in the process of establishing their reputation.

We find negative and statistically significant coefficients for cash holding for both sectors, but these are very small in magnitude. The level of cash held by firms seems to decrease the probability of achieving HGF status mainly among incumbents for both manufacturing and service sectors. A large amount of cash holding may indicate a lack of investment opportunities or capabilities, which may be detrimental for business growth (Jensen 1987), as idle cash is accumulated and is not easily invested into the production process.

Being an exporter and/or a multinational is often regarded as an indicator of internationalisation. In the manufacturing sector, exporting is a significant driving force of achieving $\mathrm{HGF}$ status, but only for firms that are over 5 years old, which is due to the experience effect that takes time to build up. This is consistent with the evidence that younger firms first focus on their home market, before starting to export into other countries (Girma and Kneller 2005). It is interesting to note the striking contrast between the impact of internationalisation on HGF incidence between the manufacturing and the service sector. Being a multinational in the service sector significantly increases a firm's likelihood to achieve HGF status, regardless of age group. This is likely driven by successful service firms replicating successful business models in other countries as well as its management practices (Battisti and Lona 2009), showing that the highgrowth service sector is not just focused on the UK economy. However, it does not have a significant effect in the manufacturing sector.

All the estimations include regional-level variables. However, as the focus of our analysis is mainly on the 
firm-level characteristics, the regional-level variables act as controls and thus are not explicitly discussed. ${ }^{12}$

\subsection{Dynamics of high growth and path dependence}

A potential drawback of the static model of highgrowth determinants is that it fails to take into account a firm's past HGF experience or path dependence. If a firm has experience of being a high-growth performer, it is likely to possess firm specificity that links with the drivers of high growth and hence is more likely to sustain its HGF status. To ensure that the results found in the static model are robust to the potential highgrowth path dependence, we adopt the standard dynamic panel probit estimator and the dynamic probit estimator due to Wooldridge (2005). ${ }^{13}$ Technically, the past HGF experience can be captured by a lagged HGF experience dummy in the model, which is estimated by a random effects panel probit estimator with a dynamic term. Wooldridge (2005) addresses the initial condition problem and delivers consistent estimates. Hence, the approach deals with firm unobserved heterogeneity that is intrinsic to firms from the initial period of observation, which may induce endogeneity concerns in the model. The important finding of the two dynamic probit model estimations is that TFP growth remains a highly significant determinant of HGF incidence for most model specifications, which lends robustness to our previous results. Higher TFP growth, on average, increases the likelihood of a firm entering a high-growth period, for both manufacturing and service sectors. The results consistently hold for incumbents for both sectors and also new service firms. The important message from our analysis is that HGF status is not a random event and productivity growth is a key determinant.

\section{HGF experience: a self-reinforcing process}

Having established that productivity growth is a significant driver of HGF prevalence, we turn our

\footnotetext{
12 The estimates of the regional level environmental variables are not reported or discussed in the text, but are available upon request.

13 For the results of the Wooldridge's dynamic probit estimations, see the online appendix.
}

attention to the productivity implications of high growth. Tables 5 and 6 show quantile regression results of the productivity effects once a firm has achieved HGF status. We find that HGF experience helps to improve TFP growth, and this finding holds along the entire TFP growth distribution for both the manufacturing and service sectors. A firm that has had a fast growth experience is more likely to display higher TFP growth later on. In particular, the coefficients increase steadily along the quantiles of TFP growth and peak towards the top quantile of TFP growth. This means that HGF experience generates even better results for firms that show higher productivity growth, and this is particularly the case for the manufacturing sector.

Firm age and size show similar associations with TFP growth across both sectors. Before the median level of TFP growth, they appear to have a positive impact and afterwards turn negative. This suggests that incumbents and larger firms are more likely to improve the productivity rate at the lower end of the distribution. At the higher end of the TFP growth distribution, younger and smaller firms are able to achieve higher productivity growth (Evans 1987; Geroski 1995; Caves 1998; Cabral and Mata 2003; Du and Girma 2012).

It is interesting to observe that intangible assets have a different impact on manufacturing and service firms. For manufacturing firms, the positive and significant impact only exists at and above the 50th percentile of TFP growth. For the service sector, intangible assets are positive and significant across the entire TFP growth distribution, which could be due to IT departments having a more direct role in strategy development than is the case in the manufacturing industries (Sohal et al. 2001). Sohal et al. (2001) also find that service industries employ IT to enhance the value of products and services to a greater extent than in the manufacturing sector, which can subsequently lead to higher TFP growth.

Labour quality proxied by average wage relates differently to a firm's TFP growth in the manufacturing and in the service sector. For manufacturing, higher wages could be an indicator for a higher number of skilled workers, which would then translate into higher TFP growth. If a service firm pays more for its labour, which typically is the most important cost factor facing the firm, then this is likely to lower the TFP growth of the firm. However, whilst we have not 
Table 5 HGF experience and TFP growth: quantile regression analysis (manufacturing sector)

\begin{tabular}{|c|c|c|c|c|c|}
\hline $\begin{array}{l}\text { Dep: TFP } \\
\text { growth } \\
\text { Variables }\end{array}$ & $\begin{array}{l}(1) \\
\mathrm{q} 10\end{array}$ & $\begin{array}{l}(2) \\
q 25\end{array}$ & $\begin{array}{l}(3) \\
\text { q50 }\end{array}$ & $\begin{array}{l}(4) \\
\text { q75 }\end{array}$ & $\begin{array}{l}(5) \\
\text { q90 }\end{array}$ \\
\hline \multicolumn{6}{|l|}{ High-growth firm } \\
\hline $\mathrm{HGF}_{i t-1}$ & $\begin{array}{l}0.0283 * * * \\
(0.00524)\end{array}$ & $\begin{array}{l}0.0457 * * * \\
(0.00403)\end{array}$ & $\begin{array}{l}0.0655 * * * \\
(0.00353)\end{array}$ & $\begin{array}{l}0.120 * * * \\
(0.00590)\end{array}$ & $\begin{array}{l}0.208 * * * \\
(0.00728)\end{array}$ \\
\hline \multicolumn{6}{|c|}{ Firm characteristics } \\
\hline $\mathrm{Age}_{t}$ & $\begin{array}{l}0.000549 * * * \\
(8.45 \mathrm{e}-05)\end{array}$ & $\begin{array}{l}0.000274 * * * \\
(5.06 \mathrm{e}-05)\end{array}$ & $\begin{array}{l}3.46 \mathrm{e}-05 \\
(2.88 \mathrm{e}-05)\end{array}$ & $\begin{array}{r}-0.00022 * * * \\
(3.80 \mathrm{e}-05)\end{array}$ & $\begin{array}{r}-0.00072 * * * \\
(7.87 \mathrm{e}-05)\end{array}$ \\
\hline Size $_{t-1}$ & $\begin{array}{l}0.0265 * * * \\
(0.0033)\end{array}$ & $\begin{array}{l}0.00884 * * * \\
(0.0021)\end{array}$ & $\begin{array}{c}-0.0132 * * * \\
(0.00097)\end{array}$ & $\begin{array}{c}-0.0355^{* * *} \\
(0.0025)\end{array}$ & $\begin{array}{c}-0.0614 * * * \\
(0.0054)\end{array}$ \\
\hline $\begin{array}{l}\text { Intangible assets } \\
\text { ratio }_{t-1}\end{array}$ & $\begin{array}{c}-6.71 \mathrm{e}-07 \\
(1.22 \mathrm{e}-06)\end{array}$ & $\begin{array}{r}-4.37 \mathrm{e}-07 \\
(4.31 \mathrm{e}-07)\end{array}$ & $\begin{array}{l}8.54 \mathrm{e}-07 * * * \\
(2.82 \mathrm{e}-07)\end{array}$ & $\begin{array}{c}1.21 \mathrm{e}-06^{*} \\
(6.56 \mathrm{e}-07)\end{array}$ & $\begin{array}{l}2.57 \mathrm{e}-06 * * \\
(1.17 \mathrm{e}-06)\end{array}$ \\
\hline Average wage en $_{t-1}$ & $\begin{array}{l}0.0724 * * \\
(0.0283)\end{array}$ & $\begin{array}{c}0.0227 \\
(0.0230)\end{array}$ & $\begin{array}{c}0.0148 \\
(0.0129)\end{array}$ & $\begin{array}{l}0.0466 * \\
(0.0279)\end{array}$ & $\begin{array}{l}0.105 * * \\
(0.0447)\end{array}$ \\
\hline Cash flow $t-1$ & $\begin{array}{c}-5.42 * * * \\
(0.295)\end{array}$ & $\begin{array}{c}-2.93 * * * \\
(0.242)\end{array}$ & $\begin{array}{c}-1.65^{* * *} \\
(0.160)\end{array}$ & $\begin{array}{c}-1.56^{* * *} \\
(0.221)\end{array}$ & $\begin{array}{c}-2.04 * * * \\
(0.489)\end{array}$ \\
\hline Export $_{t-1}$ & $\begin{array}{r}-0.0206 \\
(0.0131)\end{array}$ & $\begin{array}{r}-0.00519 \\
(0.00516)\end{array}$ & $\begin{array}{l}0.0110 * * * \\
(0.00375)\end{array}$ & $\begin{array}{l}0.0282 * * * \\
(0.00534)\end{array}$ & $\begin{array}{l}0.0445 * * * \\
(0.00987)\end{array}$ \\
\hline MNE & $\begin{array}{l}0.0377 * * * \\
(0.0105)\end{array}$ & $\begin{array}{l}0.0179 * * * \\
(0.00493)\end{array}$ & $\begin{array}{l}0.00878 * * \\
(0.00418)\end{array}$ & $\begin{array}{c}0.00639 \\
(0.00421)\end{array}$ & $\begin{array}{l}0.00809 \\
(0.0126)\end{array}$ \\
\hline Observations & 32,045 & 32,045 & 32,045 & 32,045 & 32,045 \\
\hline
\end{tabular}

The quantile regressions include the NUTS 2 regional-level variables, including unemployment rate, air traffic, GDP growth, and patent counts, year dummy and NACE 2-digit industrial sector dummies

Robust standard errors in parentheses, *** $p<0.01$; ** $p<0.05 ; * p<0.1$

tested this in our model, this relationship is likely to be different for industries such as banking or consultancy where wage increases are to a lesser extent correlated with productivity increases (Griffith et al. 2003).

For manufacturing firms, cash holding has a negative impact on TFP growth across the entire TFP growth distributions. Whilst the same result is found for service firms at the upper end of the TFP growth distribution, holding more cash boosts TFP growth at the lower end of the TFP growth distribution.

Exporting is only positively associated with TFP growth at the higher end of the TFP growth distribution in the manufacturing sector, whilst it has a positive (but not always significant) impact across the entire distribution in the service sector. If a manufacturing firm has a high growth rate, then being an exporter could boost TFP growth, but this effect does not occur in those manufacturing firms with a lower growth rate. In the service sector, firms are often either multinationals, such as most banks or insurance firms, or firms with a very confined local market, such as real estate or education. However, firms involved in foreign markets are more likely to significantly improve their TFP growth. The results are in line with Girma and Kneller (2005) for the UK service sector, Girma and Görg (2007) for UK manufacturing plants and Hijzen et al. (2007) for Japanese firms covering mining, manufacturing, and wholesale/retail trade sectors.

Overall, these results describe HGF experience as a self-reinforcing process, where more productive firms are more likely to accomplish HGF status and in turn HGFs are more likely to achieve higher productivity growth. The policy implications of our findings are reassuring. Appropriately designed measures and instruments to stimulate high growth are expected to deliver more than just short-term sales boosts. Our findings suggest, for the first time in the literature, that (successful) high growth-stimulating policies may have a positive side effect in that productivity is stimulated as well.

Furthermore, we discover that firm characteristics such as age and size, and firm resources and strategies 
Table 6 HGF experience and TFP growth: quantile regression analysis (service sector)

\begin{tabular}{|c|c|c|c|c|c|}
\hline $\begin{array}{l}\text { Dep: TFP } \\
\text { growth } \\
\text { Variables }\end{array}$ & $\begin{array}{l}(1) \\
\text { q10 }\end{array}$ & $\begin{array}{l}(2) \\
q 25\end{array}$ & $\begin{array}{l}(3) \\
q 50\end{array}$ & $\begin{array}{l}(4) \\
q 75\end{array}$ & $\begin{array}{l}(5) \\
q 90\end{array}$ \\
\hline \multicolumn{6}{|c|}{ High-growth firm } \\
\hline $\mathrm{HGF}_{i t-1}$ & $\begin{array}{c}0.0142 * * \\
(0.00554)\end{array}$ & $\begin{array}{l}0.0387 * * * \\
(0.00223)\end{array}$ & $\begin{array}{l}0.0611 * * * \\
(0.00290)\end{array}$ & $\begin{array}{c}0.119 * * * \\
(0.00375)\end{array}$ & $\begin{array}{l}0.178 * * * \\
(0.00749)\end{array}$ \\
\hline \multicolumn{6}{|c|}{ Firm characteristics } \\
\hline $\mathrm{Age}_{t}$ & $\begin{array}{l}0.000559 * * * \\
(0.0001)\end{array}$ & $\begin{array}{l}0.000185^{* * * *} \\
(0.0001)\end{array}$ & $\begin{array}{c}-0.00016^{* * *} \\
(0.0001)\end{array}$ & $\begin{array}{c}-0.00063^{* * *} \\
(0.0001)\end{array}$ & $\begin{array}{c}-0.00149 * * * \\
(0.0001)\end{array}$ \\
\hline Size $_{t-1}$ & $\begin{array}{c}0.00806 * * * \\
(2.32 \mathrm{e}-06)\end{array}$ & $\begin{array}{c}0.00217 * * * \\
(8.27 \mathrm{e}-07)\end{array}$ & $\begin{array}{r}-0.00397 * * * \\
(5.64 \mathrm{e}-07)\end{array}$ & $\begin{array}{l}-0.0119 * * * \\
(9.03 \mathrm{e}-07)\end{array}$ & $\begin{array}{c}-0.0255^{* * *} \\
(1.66 \mathrm{e}-06)\end{array}$ \\
\hline $\begin{array}{l}\text { Intangible } \\
\text { assets } \\
\text { ratio }_{t-1}\end{array}$ & $\begin{array}{l}0.0784 * * * \\
(0.0194)\end{array}$ & $\begin{array}{l}0.0400 * * * \\
(0.00830)\end{array}$ & $\begin{array}{l}0.0213 * * * \\
(0.00649)\end{array}$ & $\begin{array}{l}0.0428 * * * \\
(0.0147)\end{array}$ & $\begin{array}{l}0.204 * * * \\
(0.0415)\end{array}$ \\
\hline $\begin{array}{l}\text { Average } \\
\text { wage }_{t-1}\end{array}$ & $\begin{array}{c}-0.00297 * * * \\
(0.000170)\end{array}$ & $\begin{array}{r}-0.00157 * * * \\
(8.64 \mathrm{e}-05)\end{array}$ & $\begin{array}{r}-0.00066 * * * \\
(5.54 \mathrm{e}-05)\end{array}$ & $\begin{array}{r}-0.00056^{* * * *} \\
(6.70 \mathrm{e}-05)\end{array}$ & $\begin{array}{r}-0.00081 * * * \\
(8.79 \mathrm{e}-05)\end{array}$ \\
\hline Cash flow ${ }_{t-1}$ & $\begin{array}{l}0.0015^{* *} \\
(0.0007)\end{array}$ & $\begin{array}{l}0.0012 * * * \\
(0.0003)\end{array}$ & $\begin{array}{c}0.00012 \\
(0.0001)\end{array}$ & $\begin{array}{c}-0.001 * * * \\
(0.0003)\end{array}$ & $\begin{array}{r}-0.0002 \\
(0.0006)\end{array}$ \\
\hline Export $_{t-1}$ & $\begin{array}{c}0.00195 \\
(0.00286)\end{array}$ & $\begin{array}{c}0.00137 * * \\
(0.000693)\end{array}$ & $\begin{array}{l}0.000970 * * \\
(0.000423)\end{array}$ & $\begin{array}{c}0.000952 \\
(0.00131)\end{array}$ & $\begin{array}{c}0.00433 \\
(0.00501)\end{array}$ \\
\hline MNE & $\begin{array}{l}0.0380 * * * \\
(0.00660)\end{array}$ & $\begin{array}{l}0.0226 * * * \\
(0.00305)\end{array}$ & $\begin{array}{l}0.0135^{* * * *} \\
(0.00244)\end{array}$ & $\begin{array}{l}0.0152 * * * \\
(0.00378)\end{array}$ & $\begin{array}{l}0.0148 * * \\
(0.00630)\end{array}$ \\
\hline Observations & 78,588 & 78,588 & 78,588 & 78,588 & 78,588 \\
\hline
\end{tabular}

The quantile regressions include the NUTS 2 regional-level variables, including unemployment rate, air traffic, GDP growth, and patent counts, year dummy and NACE 2-digit industrial sector dummies

Robust standard errors in parentheses, *** $p<0.01$; ** $p<0.05$; $* p<0.1$

such as intangible assets, wage, cash flow, trade and outward investment directly affect TFP growth, besides their impact in shaping high sales growth experience. However, these effects differ in magnitude. For example, export and outward investment are more helpful in driving manufacturing firm TFP growth, but their effects on subsequent high growth are not obvious. In contrast, wage levels (for manufacturing only) and intangible assets are more useful in promoting both TFP growth and HGF status. Given that HGFs are more likely to achieve higher TFP growth, policy makers may consider utilising these factors as either direct channels or indirect channels (through HGF experience) to stimulate productivity growth.

\section{Conclusion}

Using a large UK firm-level dataset spanning the period of 2001-2010, this paper explores the links between TFP growth and HGF prevalence as defined in terms of sales growth. We draw the following conclusions based on the preceding analysis: (1) All else being equal, firms experiencing higher TFP growth are more likely to achieve HGF status; (2) Firms' past HGF experience helps firms to achieve higher TFP growth in the future; (3) There is considerable firm heterogeneity in what determines HGF incidence and how HGF experience affects future TFP growth, among firms at different development stages, namely for newer firms (no older than 5 years) or incumbents (older than 5 years), as well as firms across the manufacturing and service sector.

This paper provides, for the first time, consistent and strong evidence of the relationship between TFP growth and HGF incidence. We find HGF experiences a self-reinforcing process with positive TFP growth interactions. Firms with higher productivity are more likely to grow faster in sales and in turn HGFs are more likely to achieve higher productivity growth. The 
policy implications are evident. Appropriately designed measures and instruments to stimulate high growth are expected to not only directly impact shortterm sales growth, but also indirectly impact firm TFP growth that is crucial for sustainable economic growth. Moreover, wage and intangible assets are identified as indirectly affecting TFP growth through HGF experience, apart from their direct productivity enhancing effects. Policy makers may consider utilising these factors as either direct or indirect channels to stimulate productivity growth. Thus in the light of the ongoing debate about the average productivity lag in Europe compared with the United States, policy makers are hopeful that one of the ways to alleviate the gap is to support and fund innovative and rapidly growing businesses (Bravo-Biosca 2010). Identifying and supporting these HGFs is another opportunity for public policy to encourage productivity and economic growth in the UK economy.

Future research is needed to investigate the magnitudes of the potentially direct and indirect productivity growth enhancing effects and their channels, such as increasing human capital and innovation to guide policy makers to optimise the design of tools for public policy. It is also noteworthy that the evidence we provide here is based on the HGFs defined in terms of sales; the same may not be the case for HGFs defined in terms of employment, which clearly needs to be investigated.

Another worthwhile avenue for future research is to investigate the role of high growth in influencing economy-wide aggregate productivity. Disney et al. (2003) find that $90 \%$ of UK aggregate TFP growth during 1980-1992 was driven by entry, exit and the reallocation of market shares, where reallocation of market shares includes firms expanding (for example high growth in firm market share) or downsizing, either organically or through mergers and acquisitions. Linking their findings to our study highlights that HGFs may not only drive within-firm TFP growth, but also aggregate TFP growth through resource reallocation, which may further add to the importance of the high-growth phenomenon.

Acknowledgments We are grateful for helpful comments and suggestions by two anonymous referees who have helped to improve the paper considerably. This paper was written as part of a NESTA funded project on 'High Growth Firms and Impacts'. The authors acknowledge the financial support from NESTA and thank workshop participants at NESTA, particularly Albert Bravo-Biosca, Catherine Robinson, Mark Hart, Michael Anyadike-Danes and Sumon Bhaumik for their constructive comments and suggestions on an earlier version of the paper. We also thank Yundan Gong for the input in the project and Chris Jones for the support for revising the final version of the paper.

Open Access This article is distributed under the terms of the Creative Commons Attribution License which permits any use, distribution, and reproduction in any medium, provided the original author(s) and the source are credited.

\section{References}

Abowd, J. M., Haltiwanger, J., Jarmin, R., Lane, J., Lengermann, P., McCue, K., et al. (2005). The relation among human capital, productivity, and market value: building up from micro evidence. In C. Corrado, J. Haltiwanger, \& D. Sichel (Eds.), Measuring capital in the new economy (pp. 153-198). Chicago and London: University of Chicago Press.

Acs, Z., Parsons, W., \& Tracy, S. (2008). High impact firms: Gazelles revisited. http://www.sba.gov/advo/research/rs32 8tot.pdf.

Anyadike-Danes, M., Bonner, K., Hart, M., \& Mason, M. (2009). Measuring business growth: High growth firms and their contribution to employment in the UK. London: NESTA.

Anyadike-Danes, M., \& Hart, M. (2012). Accounting for the contribution of high growth firms to job creation. London: NESTA.

Baily, M., Bartelsman, E. J., \& Haltiwanger, J. C. (1996). Downsizing and productivity growth: Myth or reality? Small Business Economics, 8(4), 259-278.

Bartelsman, E. J., \& Dhrymes, P. J. (1998). Productivity dynamics: US manufacturing plants, 1972-1986. Journal of Productivity Analysis, 9(1), 5-34.

Bartelsman, E. J., \& Doms, M. (2000). Understanding productivity: Lessons from longitudinal microdata. Journal of Economic Literatures, 38(3), 569-594.

Bartoloni, Eleonora. (2013). Capital structure and innovation: Causality and determinants. Empirica, 40(1), 111-151.

Battisti, G., \& Lona, A. (2009). The UK productivity gap in the service sector: Do management practices matter? International Journal of Productivity and Performance Management, 58(8), 727-747.

Baumol, W. J. (1967). Macroeconomics of unbalanced growth: The anatomy of urban crisis. American Economic Review, 57(3), 415-426.

Bernard, A. B., \& Jensen, B. (1999). Exceptional exporter performance: Cause, effect or both? Journal of International Economics, 47, 1-25.

BERR (2008). High growth firms in the UK: Lessons from an analysis of comparative UK performance. BERR economics paper 03 .

Birch, D. L. (1987). Job generation in America. New York: The Free Press.

Bloom, N., \& Van Reenen, J. (2007). Measuring and explaining management practices across firms and countries. The Quarterly Journal of Economics, 122(4), 1351-1408. 
Boning, B., Ichniowski, C., \& Shaw, K. (2007). Opportunity counts: Teams and the effectiveness of production incentives. Journal of Labor Economics, 25(4), 613-650.

Bravo-Biosca, A. (2010). Growth dynamics: Exploring business growth and contraction in Europe and the US. NESTA research report.

Bravo-Biosca, A. (2011). A look at business growth and contraction in Europe. NESTA working paper 11/02.

Cabral, L., \& Mata, J. (2003). On the evolution of the firm size distribution. American Economic Review, 93, 1075-1090.

Carpenter, R. E., Fazzari, S. M., \& Petersen, B. C. (1994). Inventory investment, internal-finance fluctuations and the business-cycle. Brookings Papers on Economic Activity, 2, 75-138.

Caves, R. E. (1998). Industrial organization and new findings on turnovers and mobility of firms. Journal of Economic Literature, 36(4), 1947-1982.

Chen, M. J., \& Guariglia, A. (2013). Financial constraints and firm productivity in China: Do liquidity and export behaviour make a difference? Journal of Comparative Economics, 41(4), 1123-1140.

Coad, A. (2009). The growth of firms: A survey of theories and empirical evidence. Cheltenham, UK: Edward Elgar.

Coad, A., Cowling, M., \& Siepel, J. (2012). Growth processes of high-growth firms in the UK. NESTA working paper no. $12 / 10$.

Criscuolo, C., \& Martin, R. (2007). Multinationals and U.S. productivity leadership: Evidence from Great Britain. The Review of Economics and Statistics, 91(2), 263-281.

Cuneo, P., \& Mairesse, J. (1983). Productivity and R\&D at the firm level in French manufacturing. NBER working paper no. 1068. National Bureau of Economic Research, Inc.

Dal Borgo, M, Goodridge, P, Haskel, J., \& Pesole, A. (2012). Productivity and growth in UK industries: An intangible investment approach. Oxford Bulleting of Economics and Statistics. http://onlinelibrary.wiley.com/doi/10.1111/j.14680084.2012.00718.x/abstract.

Dale, S. (2011). Productivity and monetary policy. Speech given at the South Tyneside Manufacturing Forum, Bank of England. http://www.bankofengland.co.uk/publications/Docu ments/speeches/2011/speech519.pdf.

Daunfeldt, S. O., Elert, N., \& Johansson, D. (2010). The economic contribution of high-growth firms: Do definitions matter?. Stockholm: The Ratio Institute.

Davidsson, P., \& Delmar, F. (2006). High-growth firms and their contribution to employment: The case of Sweden 1987-96. In P. Davidsson, F. Delmar, \& J. Wiklund (Eds.), Entrepreneurship and the growth of the firm. Cheltenham, UK: Edward Elgar.

Delmar, F., Davidsson, P., \& Gartner, W. (2003). Arriving at the high-growth firm. Journal of Business Venturing, 18, 189-216.

Deschryvere, M. (2008). High growth firms and job creation in Finland. Working paper 1144, Research Institute of the Finnish Economy, Helsinki.

Disney, R., Haskel, J., \& Heden, Y. (2003). Restructuring and productivity growth in UK manufacturing. Economic Journal, 113, 666-694.

Doms, M. E., Dunne, T., \& Troske, K. (1997). Workers, wages and technology. Quarterly Journal of Economics, 112(1), 253-290.
Driffield, N., Du, J., \& Girma, S. (2008). Optimal geographic diversification and firm performance: Evidence from the UK. Journal of Productivity Analysis, 30(2), 145-154.

Driffield, N., Love, J. H., \& Menghinello, S. (2010). The multinational enterprise as a source of international knowledge flows: Direct evidence from Italy. Journal of International Business Studies, 41, 350-359.

Du, J., \& Girma, S. (2007). Finance and firm export in China. Kyklos, 60(1), 37-54.

Du, J., \& Girma, S. (2012). Firm size, source of finance and growth: Evidence from China. International Journal of the Economics of Business, 19(3), 397-419.

Du, J., \& Temouri, Y. (2010). Internationalisation and high growth firms: The OECD experience. Mimeo.

Dunning, J. H., \& Cantwell, J. A. (1991). MNEs, technology, and the competitiveness of European industries. In G. R. Faulhaber \& G. Tamburini (Eds.), European economic integration (pp. 117-148). Boston: Kluwer.

Edward, P., \& Lazear, P. E. (2000). Performance pay and productivity. American Economic Review, 90(5), 1346-1361.

EUROSTAT-OECD (2007). A manual of business demography statistics.

Evans, D. (1987). The relationship between firm growth, size and age: Estimates for 100 manufacturing industries? Journal of Industrial Economics, 35, 567-581.

Fazzari, S. M., Hubbard, R. G., \& Petersen, B. C. (1988). Financing constraints and corporate investment. Brookings Papers on Economic Activity, 1, 141-195.

Fox, J. T., \& Smeets, V. (2011). Does input quality drive measured differences in firm productivity? NBER working papers 16853, National Bureau of Economic Research, Inc.

Ganotakis, P., \& Love, J. H. (2012). Export propensity, export intensity and firm performance: The role of the entrepreneurial founding team. Journal of International Business Studies, 43, 693-718.

Geroski, P. A. (1995). What do we know about entry? International Journal of Industrial Organization, 13(4), 421-440.

Girma, G., \& Gong, Y. (2008). FDI, linkages and the efficiency of state-owned enterprises in China. The Journal of Development Studies, 44(5), 728-749.

Girma, S., \& Görg, H. (2007). Multinationals' productivity advantage: Scale or technology? Economic Enquiry, 45(2), $350-362$.

Girma, S., \& Kneller, R. (2005). Productivity levels and dynamics: UK service sector firms 1988-1998. Scottish Journal of Political Economy, 52, 736-746.

Greenaway, D., \& Kneller, R. (2007). Firm heterogeneity, exporting and foreign direct investment. Economic Journal, 117, F134-F161.

Griffith, R., Harrison, R., Haskel, J., \& Sako, M. (2003). The UK productivity gap and the importance of the service sectors. AIM briefing note, December 2003.

Griliches, Z., \& Mairesse, J. (1995). Production functions: The search for identification. NBER working paper no. 5067. National Bureau of Economic Research, Inc.

Harris, R., \& Li, Q. C. (2007). Learning-by-exporting? Firmlevel evidence for UK manufacturing and services sectors. Working paper 2007-22, University of Glasgow Business School. 
Harris, R., \& Robinson, C. (2003). Foreign ownership and productivity in the United Kingdom estimates for U.K. manufacturing using the ARD. Review of Industrial Organization, 22, 207-223.

Hart, M., \& Mcguinness, S. (2003). Small firm growth in the UK regions 1994-1997: Towards an explanatory framework. Regional Studies, 37(2), 109-122.

Helpman, E., Melitz, M. J., \& Yeaple, S. R. (2004). Export versus FDI with heterogeneous firms. American Economic Review, 94(1), 300-316.

Henrekson, M., \& Johansson, D. (2010a). Gazelles as job creators: A survey and interpretation of the evidence. Small Business Economics, 35(2), 227-244.

Henrekson, M., \& Johansson, D. (2010b). Firm growth, institutions and structural transformation. In M. Fritsch (Ed.), Handbook of research on entrepreneurship and regional development: National and regional perspectives. USA: Edward Elgar.

Hijzen, A., Tomohiko, I., \& Yasuyuki, T. (2007). The effects of multinational production on Domestic. RIETI discussion paper series 07-E-006.

Horstmann, I. J., \& Markusen, J. R. (1989). Firm-specific assets and the gains from direct foreign investment. Economica, 56(221), 41-48.

Huynh, K. P., \& Petrunia, R. J. (2010). Age effects, leverage and firm growth. Journal of Economic Dynamics and Control, 34, 1003-1013.

Ilmakunnas, P., Maliranta, M., \& Vainiomaki, J. (2004). The roles of employer and employee characteristics for plant productivity. Journal of Productivity Analysis, 21, 249-276.

Jensen, M. (1987). Agency costs of free cash flow, corporate finance, and takeovers. American Economic Review, 76(2), 323-329.

Jorgenson, D. W., Ho, M. S., \& Stiroh, K. J. (2005). Information technology and the American growth resurgence. Cambridge: MIT Press.

Kirca, A. H., Hult, G. T. M., Roth, K., Cavusgil, S. T., Perry, M., Akdeniz, M. B., et al. (2011). Firm-specific assets, multinationality, and firm performance: a meta-analytic review and theoretical integration. Academy of Management Journal, 54(1), 47-72.

Kirchhoff, B. A. (1994). Entrepreneurship and dynamic capitalism: The economics of business firm formation and growth. USA: Greenwood Press.

Koenker, R., \& Bassett, G. (1978). Regression quantiles. Econometrica, 46, 33-50.

Lang, L., Ofek, E., \& Stulz, R. M. (1996). Leverage, investment, and firm growth. Journal of Financial Economics, 40, 3-29.

Levinsohn, J., \& Petrin, A. (2003). Estimating production functions using inputs to control for unobservables. Review of Economic Studies, 70(2), 317-342.

Li, X., \& Prescott, D. (2009). Measuring productivity in the service sector. New York: Mimeo.

Lichtenberg, F. R., \& Siegel, D. (1991). The impact of R\&D investment on productivity-new evidence using linked R\&D-LRD data. Economic Inquiry, 29(2), 203-229.

Lockett, A., Wiklund, J., Davidsson, P., \& Girma, S. (2011). Organic and acquisitive growth: Re-examining and extending the Penrose's growth theory. Journal of Management Studies, 48(1), 48-74.

Mason, G., Bishop, K., \& Robinson, C. (2009). Business growth and innovation: The wider impact of rapidly-growing firms in UK city-regions. London: NESTA.

Mason, C., \& Brown, R. (2010). High growth firms in Scotland. Glasgow: Scottish Enterprise.

Mason, G., Robinson, C., \& Rosazza-Bondibene, C. (2012). Sources of labour productivity growth: sectoral decompositions for Britain, 1998-2007. NESTA report.

Melitz, M. J. (2003). The impact of trade on intra-industry reallocations and aggregate industry productivity. Econometrica, 71(6), 1695-1725.

NESTA (2011). Vital growth: The importance of high-growth businesses to the recovery. http://www.nesta.org.uk/ library/documents/Vital_Growth_v19.pdf.

OECD. (1998). Technology, productivity and job creation: Best policy practices. Paris: OECD.

OECD. (2000). High-growth SMEs and employment. Paris: OECD.

OECD. (2002). High-growth SMEs: Their contribution to employment and their characteristics. Paris: OECD.

OECD. (2003). Sources of economic growth in the OECD countries. Paris: OECD.

Oliner, S. D., Sichel, D. E., \& Stiroh, K. J. (2008). Explaining a productive decade. Journal of Policy Modeling, 30(4), 633-673.

Oliveira, B., \& Fortunato, A. (2006). Firm growth and liquidity constraints: A dynamic analysis. Small Business Economics, 27(2-3), 139-156.

Olley, S. G., \& Pakes, A. (1996). The dynamics of productivity in the telecommunications equipment industry. Econometrica, 64(6), 1263-1297.

Parker, S. C., Story, D. J., \& van Witteloostuijn, A. (2010). What happens to gazelles? The importance of dynamic management strategy. Small Business Economics, 35, 203-226.

Penrose, E. T. (1959). The theory of the growth of the firm. Oxford: Basil Blackwell.

Petrin, A., \& Levinsohn, J. (2012). Measuring aggregate productivity growth using plant-level data. RAND Journal of Economics, 43(4), 705-725.

Riley, R., Robinson, C., \& Davison, S. (2011). Skills and economic performance: The impact of intangible assets on UK productivity. Evidence report 39, UK Commission for Employment and Skills.

Roper, S., Love, J. H., \& Du, J. (2008). Modelling the innovation value chain. Research Policy, 37, 961-977.

Sohal, A. S., Moss, S., \& Ng, L. (2001). Comparing IT success in manufacturing and service industries. International Journal of Operations and Production Management, 21(1/ 2), 30-45.

Stam, E., Suddle, K., Hessels, J., \& Van Stel, A. (2009). Highgrowth entrepreneurs, public policies and economic growth. In J. Leitao \& R. Baptista (Eds.), Public policies for fostering entrepreneurship: A European perspective (pp. 91-110). New York: Springer.

Storey, D. J. (1994). Understanding the small business sector. London: International Thomson Business Press.

Syverson, C. (2011). What determines productivity? Journal of Economic Literature, 49(2), 326-365. 
Van Ark, B., O’Mahoney, M., \& Timmer, M. P. (2008). The productivity gap between Europe and the United States: Trends and causes. Journal of Economic Perspectives, 22(1), 25-44.

Van Biesebroeck, J. (2003). Productivity dynamics with technology choice: An application to automobile assembly. Review of Economic Studies, 70(1), 167-198.

Wagner, J. (2007). Exports and productivity: A survey of the evidence from firm-level data. The World Economy, Wiley Blackwell, 30(1), 60-82.

Wagner, J. (2012). Average wage, qualification of the workforce and export performance in German enterprises: Evidence from KombiFiD data. Journal for Labour Market Research, 45(2), 161-170.

Wooldridge, J. M. (2005). Simple solutions to the initial conditions problem in dynamic, nonlinear panel data models with unobserved heterogeneity. Journal of Applied Econometrics, 20(1), 39-54.

Wooldridge, J. M. (2009). On estimating firm-level production functions using proxy variables to control for unobservables. Economics Letters, 103, 112-114. 